\title{
Anna Engelking
}

engelking@ispan.waw.pl

Instytut Slawistyki PAN

\section{MACEDOŃSKIE TROBRIANDY. JÓZEF OBRĘBSKI I PIERWSZE BADANIA WSI EUROPEJSKIEJ W PARADYGMACIE FUNKCJONALIZMU}

\author{
Macedonian Trobriand Islands. \\ Józef Obrębski and the First Functionalist Research \\ of the European Village
}

Streszczenie: Artykuł dotyczy początków drogi naukowej Józefa Obrębskiego (1905-1967), ucznia Bronisława Malinowskiego, polskiego prekursora badań nad etnicznością, płcią kulturową oraz studiów postkolonialnych. Jego prace, nowatorskie i wyprzedzające swój czas, w większości nie zostały opublikowane, Obrębski nie funkcjonuje więc $\mathrm{w}$ antropologicznym mainstreamie. We wczesnych latach 30 . prowadził on badania terenowe w prawosławnych społecznościach chłopskich Macedonii. Był pierwszym antropologiem, który zastosował etnograficzną metodę terenową $\mathrm{i}$ teorię funkcjonalną $\mathrm{w}$ badaniach wsi europejskiej. Obrębski, pragnąc znaleźć wśród górali macedońskich swoje Trobriandy, analizował m.in. strukturę społeczną i rytuał w badanych społecznościach pod kątem relacji między płciami. Koncentrował się na społecznych, ekonomicznych i symbolicznych aspektach prawa małżeńskiego (np. odkup za żonę, małżeństwo przez ucieczkę czy stosunki seksualne). Badał także - metodą „obiektywnej obserwacji i bezpośredniego doświadczenia”, jak ją nazywał - czarownictwo i sekretne praktyki magii miłosnej, jak również inne rytuały sprawowane przez kobiety z perspektywy zarówno konfliktu, jak i współpracy między płciami. II wojna światowa, a następnie emigracja Obrębskiego spowodowały, że nie ukończył on i nie opublikował macedońskich monografii, nad którymi pracował. Autorka artykułu przygotowuje obecnie do druku krytyczną edycję pism uczonego z intencją wprowadzenia jego dorobku do antropologicznego obiegu. 
Słowa kluczowe: Józef Obrębski, Bronisław Malinowski, Macedonia, funkcjonalizm, badania terenowe, historia antropologii. Abstract: The article deals with the beginnigs of the scientific career of Józef Obrębski (1905-1967), a student of Malinowski and Polish precursor of ethnic, gender and postcolonial studies. His works, although extremely innovative at his time, remained mostly unpublished and thus Obrębski remains unknown in the anthropological mainstream. Obrębski conducted field research in Orthodox peasant communities in Macedonia in the early 1930s. He was the first anthropologist who applied Malinowski's ethnographic field method together with his functionalist theory to European village. Obrębski, seeking for his Trobriand Islands among Macedonian highlanders, analysed social structure and ritual in the researched communites in terms of gender relations. He focused on the social, economic and symbolic contexts of marital law (such as, for instance, bridewealth, marriage by eloption or sexual relations). Using the method of ,objective observation and direct experience", as he called it, he also researched witchcraft and the secret practices of love magic as well as other rituals performed by women in the terms of both gender power struggle and cooperation. Due to the events of the World War II and his subsequent emigration from Poland he failed to complete and publish his Macedonian field monographs. The author of this paper aims to reintroduce Obrębski's work to the contemporary anthropology by preparing a critical edition of his writings. Keywords: Józef Obrębski, Bronisław Malinowski, Macedonia, functionalism, fieldwork, history of anthropology. 
Macedońskie Trobriandy. Józef Obrębski i pierwsze badania...

\section{Wprowadzenie}

Anna Kutrzeba-Pojnarowa nazwała kiedyś Józefa Obrębskiego ${ }^{1}$ „odkrywcą polskiego Trobriandu, archaicznych struktur w naszym własnym kraju" (Kutrzeba-Pojnarowa 1979: 75). To chwyt retoryczny. Potraktowany dosłownie, jako opis faktów, nie wytrzymuje krytyki. Choć Obrębski jest autorem monografii Polesie archaiczne (por. Obrębski 2007), nie był bynajmniej odkrywcą archaicznych aspektów kultury tego regionu. Co ważniejsze, w ,archaicznym Polesiu” interesował go przede wszystkim fenomen dezorganizacji owej, powszechnie mityzowanej, archaiczności; badał procesy modernizacji (w tym nacjonalizacji). Także od strony metodologicznej nie był Obrębski podczas badań na Polesiu pryncypialnym funkcjonalistą; stosował eklektyzm metodologiczny (por. Engelking 2007b).

Gdyby jednak zestawienie Obrębskiego z Malinowskim i terenu jego badań etnograficzych z Trobriandami odnieść do ekspedycji terenowej, którą odbył wcześniej, przed Polesiem, metafora Kutrzeby-Pojnarowej miałaby pełne uzasadnienie. Chodzi o badania, jakie prowadził w latach 1932-1933 w jugosłowiańskiej wówczas Macedonii², wśród górali regionu Porecze. Były to pierwsze etnograficzne badania terenowe wsi europejskiej konsekwentnie przeprowadzone od strony teoretycznej i metodologicznej w paradygmacie funkcjonalizmu.

\section{Uczeń Malinowskiego z Moszyńskim w tle}

Rolniczo-pasterska społeczność górali Porecza żyła, jak pisał Obrębski, „dalej niż na peryferiach cywilizacji” (OC: Giaurowie). Była to grupa w znacznym stopniu izolowana pod względem komunikacyjnym, gospodarczym, społecznym i świadomościowym. Celem młodego, 27-letniego badacza był etnograficzny opis tej społeczności: ,jej życia, zwyczajów, instytucji” (OC: Giaurowie), w tym w szczególności organizacji rodzinnej i systemu magiczno-religijnego.

\footnotetext{
${ }^{1}$ Józef Obrębski żył w latach 1905-1967; informacje biograficzne zob. Engelking 2007a.

${ }^{2} \mathrm{~W}$ tym okresie Macedonia Wardarska, nazywana też południową Serbią, wchodziła w skład Królestwa Jugosławii.
} 
Prosta i oszczędna, kultura ludowa Porecza - pisał - stanowi system jasny, zwarty, konsekwentny, wykazujący swoistą logikę, umiar i równowagę. Stąd dla badacza, którego zainteresowania nie podążają za (...) pozornymi dziwacznościami kultury prymitywnej (...), lecz [który] zdąża do poznania skomplikowanego mechanizmu kultury prymitywnej, analizy jej poszczególnych instytucji i aspektów, i wykrycia związków, spajających życie grupy pierwotnej w pewien określony i zamknięty system społeczno-kulturalny, Porecze stanowić może idealny wprost przedmiot studiów (Obrębski 2005a: 26-27).

Nietrudno dostrzec, że Obrębski, konceptualizując swój przedmiot badań, odnosił go do modelu, jaki stanowiła opisana przez Malinowskiego społeczno-kulturowa rzeczywistość Wysp Trobrianda.

Nie ulega najmniejszej wątpliwości, że teoretyczną i metodologiczną inspirację macedońskich badań Obrębskiego stanowiły monografie trobriandzkie Malinowskiego ${ }^{3}$. Dwie z nich - Argonauts of the Western Pacific (1922, wyd. polskie 1967) i The Sexual Life of Savages in North-Western Melanesia (1929, wyd. polskie 1938) - czytał w angielskim oryginale na długo przed podjęciem badań na Poreczu, jeszcze podczas studiów w Polsce. Natomiast Coral Gardens and Their Magic (1935, wyd. polskie 1986), które ukazało się drukiem dwa lata po jego wyjeździe z Macedonii, było mu znane wcześniej od nieoczywistej, bo warsztatowej strony: pracował nad tą książką razem z jej autorem ${ }^{4}$, przebywając z Malinowskim jako jego asystent badawczy w Oberbozen i w Tamaris w latach 1931-19325. Nauka i inspiracje, jakie otrzymał od Malinowskiego i zastosował na Poreczu, nie były zatem zapośredniczone.

${ }^{3}$ Obrębski czerpał z całej twórczości Malinowskiego. Materiały terenowe z jego badań w Macedonii i ich opracowania świadczą, że przemyślał zwłaszcza takie prace, jak Magic, Science and Religion (1925), Crime and Custom in Savage Society (1926), Myth in Primitive Psychology (1926), Sex and Repression in Savage Society (1927), Culture (1931), Law and Custom (1934). Prace Malinowskiego o prawie, zwyczaju i zbrodni przetłumaczył na polski pod koniec lat trzydziestych (Malinowski 1938a, 1938b).

${ }^{4}$ W „Przedmowie Autora” do Ogrodów koralowych Bronisław Malinowski pisał: „W opracowaniu mego materiału otrzymałem znaczną pomoc ze strony asystentów badawczych, co umożliwiła Fundacja Rockefellera. W szczególności dr Józef Obrębski i panna Agnes Drew towarzyszyli mi w wydobyciu materiału z moich notatek terenowych (...). Ponadto rękopis w na pół ukończonej formie był czytany na jednym z moich seminariów, rozdział przez każdego uczestnika, a następnie krytykowany i dyskutowany, z czego ja sam, jak również - mam nadzieję - książka, odnieśliśmy znaczną korzyść” (Malinowski 1986: 23).

${ }^{5}$ Malinowski spędzał tam swój urlop sabatyczny - w Oberbozen w Tyrolu od lipca do września 1931 i w Tamaris na Riwierze od października 1931 do kwietnia 1932. 
Macedońskie Trobriandy. Józef Obrębski i pierwsze badania...

Obrębski należał do kręgu bliskich uczniów Malinowskiego ${ }^{6}$ (por. Kuper 1987: 30-36). Był uczestnikiem jego słynnego seminarium $\mathrm{z}$ antropologii społecznej w London School of Economics and Political Science ${ }^{7}$, pod jego kierunkiem napisał też doktorat ${ }^{8}$. Bezpośredni kontakt nauczyciela i ucznia ${ }^{9}$ trwał pełne trzy lata: od listopada 1930 roku, kiedy Obrębski przyjechał do Londynu jako stypendysta fundacji Rockefellera, do stycznia 1934 roku, kiedy to otrzymał w LSE stopień doktora antropologii społecznej. Nic zatem dziwnego, że jego teoretyczne kredo, sformułowane we wstępie do podsumowującej badania macedońskie monografii, brzmiało tak, jakby wypowiedział je Malinowski: „Opis etnograficzny musi (...) posługiwać się metodą socjologiczną. Ukazuje on typy i odmiany kultury na tle życia zbiorowego społeczności pierwotnych" (OC: Giaurowie). Na gruncie, z którego Obrębski wyrósł - młodej, instytucjonalizującej się dopiero akademickiej etnografii/etnologii w peryferyjnej Polsce - brzmiało to o ile nie rewolucyjnie, to z całą pewnością nowatorsko.

Józef Obrębski zdobył wykształcenie i stopień magistra na tym samym Uniwersytecie Jagiellońskim w Krakowie, którego absolwentem i doktorem (1908) był dwie dekady przed nim Bronisław Malinowski. Studiował etnografię Słowian i filologię słowiańską (w latach 1925-1930) w powołanej w tym uniwersytecie eksperymentalnej jednostce, Studium Słowiańskim, realizującym koncepcję słowianoznawstwa zintegrowanego, którą można porównać z dzisiejszymi interdyscyplinarnymi Slavic Studies (por. Engelking 2018). Równolegle, już od początku studiów, był zatrudniony

\footnotetext{
${ }^{6}$ Więcej na temat relacji Obrębski-Malinowski i zaangażowania Obrębskiego w upowszechnianie funkcjonalizmu w Polsce por. Engelking 2004.

${ }^{7}$ Jego środowisko koleżeńskie na seminarium tworzyli m. in.: Edward E. Evans-Pritchard, Raymond Firth, Meyer Fortes, Felix M. Keesing, Lucy Mair, Siegfried Nadel, Audrey Richards.

${ }^{8}$ Była to rozprawa Family Organisation Among Slavs as Reflected in the Custom of Couvade (Organizacja rodziny u Słowian przez pryzmat zwyczaju kuwady), napisana w grudniu 1933 roku. Maszynopis (200s.) znajduje się w archiwum London School of Economics.

${ }^{9}$ Obrębski i Malinowski poznali się osobiście w lipcu 1930 roku podczas pobytu Malinowskiego w Krakowie. „Podczas mego pobytu w Krakowie tego lata, w lipcu, przetestowałem Obrębskiego ze znajomości angielskiego. (...) Rozumiał mnie zupełnie dobrze, zwłaszcza gdy poruszałem tematy naukowe i jestem pewien, że będzie mógł śledzić moje wykłady od samego początku. (...) Wziąwszy pod uwagę jego kwalifikacje naukowe, specjalizację w problematyce pokrewieństwa i rodziny u Słowian oraz zdolności językowe, chcę położyć na szali całą swoją wagę dla poparcia jego aplikacji” (list Malinowskiego do Van Sickle'a, 2.10.1930, LSE; tłum. A. Engelking).
} 
w Studium Słowiańskim jako asystent, wykonujący liczne pomocnicze prace organizacyjne i redakcyjne oraz prowadzący zajęcia ze studentami. Jako etnograf i etnolog był Obrębski uczniem Kazimierza Moszyńskiego, największego bodaj w ówczesnej Europie autorytetu w zakresie etnografii Słowiańszczyzny, zaś jako lingwista - uczniem slawisty Kazimierza Nitscha. Nitsch z kolei studiował językoznawstwo u Lucjana Malinowskiego, ojca Bronisława; w młodości był korepetytorem przyszłego antropologa. W londyńskim okresie Malinowskiego to Nitsch był jego głównym korespondencyjnym kontaktem z Krakowem i z tamtejszym uniwersytetem. Wyjazd Obrębskiego na stypendium do Londynu popierali obaj, i Moszyński i Nitsch, rozumiejąc, że studia u Malinowskiego dadzą temu młodemu etnologowi, którego uważali za wyjątkowo utalentowanego, możliwości dalszego rozwoju, jakich nie mogła mu zapewnić uczelnia w Krakowie. Chodziło zarówno o rozwój jego indywidualnej kariery naukowej, jak i o mający nastąpić dzięki jego wkładowi przyszły rozwój polskiej etnologii.

Zainteresowania Obrębskiego, specjalizującego się dotychczas w kulturze materialnej (jego praca magisterska jest etnogeograficzno-typologiczną analizą narzędzi rolniczych na Półwyspie Bałkańskim ${ }^{10}$ ), ewoluowały wówczas w kierunku antropologii społecznej; swoją przyszłość naukową wiązał z badaniami organizacji społecznej wschodnio- i południowoeuropejskich chłopów. Jeszcze zanim rozstrzygnęła się kwestia jego wyjazdu do Londynu, planował - jak pisał Malinowskiemu - ,pracę terenową w najbardziej prymitywnych okolicach Białorusi”, która ,pójdzie głównie w kierunku socjologicznym i oprze się na metodach Pana Profesora, znanych mi dzięki Jego pracom, z których b[ardzo] wiele skorzystałem" (list Obrębskiego do Malinowskiego, 31.05.1930, LSE).

Jego krakowski nauczyciel etnologii, Kazimierz Moszyński ${ }^{11}$, projektował dla Obrębskiego profesorską karierę w jednej z uniwersyteckich katedr etnologicznych w Polsce. Widział go jako przyszłego specjalistę „W zakresie społecznego życia ludowego Słowian”. W liście do Johna Van Sickle'a, dyrektora biura Fundacji Rockefellera w Paryżu, który odpowiadał za stypendia z zakresu nauk społecznych, podkreślał, że takiego specjalisty „nie ma obecnie (...) ani w Polsce, ani też w żadnym innym

${ }^{10}$ Praca magisterska Obrębskiego, Rolnictwo ludowe wschodniej części pótwyspu Bałkańskiego, to seria 4 artykułów opublikowana w czasopiśmie „Lud Słowiański” w latach 1929-1931.

${ }^{11}$ Szerzej o relacji Obrębski-Moszyński zob. Engelking 2012. 
Macedońskie Trobriandy. Józef Obrębski i pierwsze badania...

państwie słowiańskim” i że Obrębski ma wszelkie predyspozycje, by „studiować prymitywne życie społeczne” w dowolnym kraju słowiańskim, co „będzie mógł uczynić z łatwością, zna bowiem wszystkie języki słowiańskie”. Widział go jako autora „krytycznych opracowań”, syntetyzujących „nadzwyczaj obfite” ,zebrane dotychczas materiały etnograficzne, dotyczące społecznego życia ludowego Słowian”, przy czym autora „ogłasza[jącego] ważniejsze swe prace po angielsku, udostępniając w ten sposób obfite materiały etnograficzne słowiańskie szerszemu światu" (list Moszyńskiego do Van Sickle'a, b.d., IEiAK UJ).

Rozpoczynając studia u Malinowskiego, był więc Obrębski bez wątpienia nadzieją polskiej etnologii ${ }^{12}$. Jego londyński nauczyciel prędko podzielił opinie krakowskich. „Zdolny, sympatyczny, inteligentny - jest on ogólnie lubiany i popularny u wszystkich, którzy go znają. (...) [U] ważam przyszłość Obr[ębskiego] za nadzwyczajnie obiecującą" - pisał Malinowski do Nitscha (10.06.1931, cyt. za: Flis, Paluch, 1985: 289). Zaś do Fundacji Rockefellera: „Co do mnie, wyrobiłem sobie nadzwyczaj pozytywną opinię o charakterze, inteligencji i pracowitości Obrębskiego i o ile jego zdrowie utrzyma się w tak dobrym stanie jak obecnie (...), jestem pewien, że będzie mógł zająć czołową pozycję wśród pracujących w naukach społecznych" (list Malinowskiego do Van Sickle'a, 3.05.1931, LSE; tłum. A. Engelking).

Jakie zatem wyniki naukowe przyniosły temu młodemu, obiecującemu antropologowi badania terenowe w Macedonii?

\section{„Trobriandzki” projekt monografii macedońskich}

Macedońską „terenówkę"13 prowadził Obrębski systematycznie przez osiem miesięcy, od sierpnia 1932 do marca 1933 roku, w kilku wsiach Górnego Porecza, mieszkając w jednym z gospodarstw w położonej najwyżej z nich, trudno dostępnej zimą wsi Wołcze. Jego gospodarze - wdowa

${ }^{12}$ Podobnie postrzegali go rówieśnicy. Oto wzmianki ze wspomnień przyjaciół: „Obrębski zapowiadał się na gwiazdę polskiej etnologii. Był wyjątkowo inteligentny. Odznaczał się też nieprzeciętnym wdziękiem” (Weintraub 1994: 15-16). „Miał świetne warunki, jak nikt w jego pokoleniu. Dostawał stypendia. Powszechnie uważano, że zrobi karierę. Uważano go za bardzo zdolnego" (Feliks Gross w rozmowie z Anną Engelking, 1996).

${ }^{13}$ Było to nieformalne określenie używane w środowisku. Obrębski posługiwał się nim m.in. w korespondencji z Moszyńskim. 
Stefkojca z dorosłymi synami Cirem i Kolem oraz ich krąg rodzinny, rodowy i sąsiedzki - stanowili mikroświat, w którym cudzoziemski etnograf funkcjonował na zasadzie „gościa-przyjaciela"14 (porecka kategoria gost-prijatel obejmuje powinowatych, kumów, pobratymów i bliskich przyjaciół).

[B]lisko sześć miesięcy spędziłem niemal jako członek zadrugi - relacjonował później Moszyńskiemu - chwytając jakby na gorącym uczynku i obserwując z bliska to, co dotychczas nie było prawie zupełnie obserwowane: intymne życie rodziny południowosłowiańskiej. (...) Oprócz szeregu cennych informacji zdobyłem rzecz najważniejszą: dobrą znajomość tego kompleksu stosunków, jakie przedstawia patriarchalna (wielka) rodzina. (...) Mam poczucie, że w temacie pokrewieństwa południowosłowiańskiego jestem bezkonkurencyjny, zarówno w znajomości faktów, jak i w teoretycznym opanowaniu tematu (list Obrębskiego do Moszyńskiego, 4.04.1933, IAiEK UJ).

Jego etnograficzną strategią była przede wszystkim aktywnie reagująca na bieg wypadków obserwacja oraz uczestnictwo (,czynny współudział w życiu wsi" ${ }^{15}$ ), a także, co oczywiste - rozmowy z otaczającymi go ludźmi; głównie były to rozmowy nieformalne, nie zaś formalne wywiady. Początki jednak były trudne - sporo czasu zajęło Obrębskiemu przełamywanie konwencjonalnych relacji z mieszkańcami wsi i ich początkowej nieufności ${ }^{16}$. Zdając sobie dobrze sprawę, że ,pod inscenizowanym wobec obcego poszanowaniem dla tradycji, prawa i zwyczaju (...) kryje się rzeczywistość daleka od sfałszowanych pozorów ideału", usiłował dotrzeć „,do dessous ich życia społecznego, zwyczajowych, niepisanych praw i skrzętnie ukrywanych skandalów i bezprawia" (OC: Skandal). Zgodnie z dyrektywą metodologiczną Malinowskiego był wyczulony na „nieustanne rozbieżności pomiędzy tym, co ludzie mówią, a tym, co robią; tym co rzeczywiście czynią i tym, co myślą" (Kuper 1987: 27) ${ }^{17}$. Był

14 „Piszący te słowa niejednokrotnie funkcjonował na obszarze Porecza jako taki gość-przyjaciel różnych rodzin poreckich" (OC: Giaurowie).

15 ,Specjalnie czynny współudział w życiu wsi, która była główną areną moich prac, pozwolił mi odkryć cały miejscowy system czarownictwa i bliżej weń wniknąć nie tylko teoretycznie, ale nawet przez praktyczny współudział w paru intrygach czarowniczych" relacjonował w monografii Czarownictwo Porecza Macedońskiego (OC: Czarownictwo).

${ }^{16}$ Szczegółowiej na ten temat zob. Bielenin-Lenczowska, Engelking 2015.

17 „Malinowski zaszczepił swoim studentom bezcenną świadomość napięcia, jakie istnieje zawsze pomiędzy tym, co ludzie mówią, a tym, co czynią, pomiędzy dążeniami jednostki a porządkiem społecznym” (Kuper: 1987: 49). 
Macedońskie Trobriandy. Józef Obrębski i pierwsze badania...

także w pełni świadomy, że badana rzeczywistość weryfikuje pierwotne założenia badacza.

Obrębski przyjechał na Porecze z zamiarem badania lokalnej organizacji rodzinnej, jednak na miejscu musiał zmierzyć się z wieloma innymi wyzwaniami:

Empiryczne badania etnologiczne, których naczelnym postulatem jest osobista bezpośrednia obserwacja (...), kryły w sobie nieuchronne niespodzianki. (...) [N]ieustanny potok zdarzeń i kolei życia wiejskiego, dokonujących się w moich oczach i niemal przy moim współudziale, rozsadził rygorystyczne i nierealne ramy, w których pragnąłem zamknąć moje studia. Z konieczności więc inne problemy i zjawiska, wykraczające poza naczelny temat życia rodzinnego, musiały zostać uwzględnione. (...) Jednym z [nich] (...) były studia nad czarownictwem - (...) nad wyraz uciążliwe ze względu na tajemniczość i konspirację, otaczające tę dziedzinę życia Poreczan. Wymagały one bardzo intymnego kontaktu z tubylcami i metod zgoła innych aniżeli operowanie kwestionariuszem i posługiwanie się indagacją (Obrębski 2005a: 27-28).

W efekcie zatem zgromadził znacznie bardziej różnorodny materiał etnograficzny, niż początkowo zamierzał. Jego zapisy terenowe i sporządzane na ich podstawie opracowania dotyczą w istocie rzeczy wszystkich sfer życia badanej społeczności: od gospodarki, przez obrzędowość doroczną i rodzinną, lecznictwo i magię, mitologię i religię, po relacje małżeńskie i instytucję rodziny w rozbudowanym kontekście społeczno-kulturowym. Zapisał kilkaset krótszych i dłuższych tekstów folkloru, w tym liczne zamawiania magiczne, sporządził również bogatą dokumentację fotograficzną (około 550 czarno-białych fotografii na kliszach szklanych).

W planach miał serię monografii. Dziś nie jest już możliwa adekwatna rekonstrukcja całości tego projektu. Tytuły i konspekty książek, a także artykułów, nad którymi w kolejnych latach z różną intensywnością pracował, ewoluowały w czasie i nie sposób już odtworzyć ich chronologii i zgodnego z finalnym zamierzeniem autora układu merytorycznego. Dzieło Obrębskiego, zachowane w formie maszynopisów i rękopisów, niedomknięte i, jak się wydaje, o niewykrystalizowanych do końca wewnętrznych delimitacjach, stanowi samo w sobie dowód słuszności fundamentalnego założenia funkcjonalizmu, mówiącego o kompleksowym i wielopłaszczyznowym charakterze rzeczywistości społecznej. 
Współczesny redaktor pism Obrębskiego, gdy stara się przyporządkować, dajmy na to, któryś z wariantów jego opisu struktury społecznej wsi Porecza do monografii o systemie magiczno-religijnym, o czarownictwie bądź o małżeństwie i rodzinie, przekonuje się namacalnie, do jakiego stopnia poszczególnych aspektów kultury nie można badać, postrzegać i opisywać w oderwaniu.

Gotowa do druku monografia Obrębskiego Macedońska wiara i obrzędy. Socjologiczny opis wierzeń i obrzędów magiczno-religijnych Porecza w serbskiej Macedonii, nad którą pracował w czasie okupacji niemieckiej, uległa zniszczeniu w czasie powstania w Warszawie w 1944 roku. Nie wiadomo też, czy jego materiały terenowe i warsztatowe zachowały się w całości. Spuścizna, którą dzisiaj dysponujemy, to cztery (najprawdopodobniej) $)^{18}$ nieukończone monografie wraz z ilustrującą je bogatą dokumentacją terenową. Giaurowie Macedonii. Opis magii i religii pasterzy z Porecza na tle zbiorowego życia ich $w s i^{19}$ to materiały do wspomnianej książki, która uległa zniszczeniu. Czarownictwo Porecza Macedońskiego ${ }^{20}$ miało ukazać się po angielsku ${ }^{21}$. Podczas pracy nad tą książką w Warszawie, w 1935 roku, po otrzymaniu od Malinowskiego egzemplarza Coral Gardens, Obrębski pisał do niego:

${ }^{18}$ Podczas redakcji naukowej (projekt w toku) są one rekonstruowane z zachowanych maszynopisów i rękopisów. Teksty Obrębskiego istnieją często w kilku nieukończonych wariantach; nie zawsze da się rozstrzygnąć, czy mamy do czynienia np. z zarysem rozdziału monografii, czy też odrębnego artykułu. Nie sposób więc definitywnie stwierdzić, nad iloma monografiami i artykułami ogółem pracował.

19 Tytuł zrekonstruowany przez redaktorkę naukową monografii. Materiały Obrębskiego zawierają kilka wariantów tego tytułu.

20 „Był to temat niewątpliwie najtrudniejszy ze względu na jego niedostępność w Macedonii. Nota bene dotychczas, mam wrażenie, ani jednego opisu systemu medycyny i magii u południowych Słowian nie ma. Praca, początkowo podjęta ze złości na skrytość i nieufność bab macedońskich, rozwinęła się dość interesująco. Rezultatem tego będzie książka o znachorkach macedońskich, którą - o ile warunki pozwolą - postaram się przygotować po angielsku. (...) Będzie dość ważnym przyczynkiem dla znajomości struktury społeczno-kulturalnej społeczeństwa patriarchalnego. Posiada dość obfitą kolekcję fotografii" (list Obrębskiego do Moszyńskiego, 4.04.1933, IAiEK UJ). Pierwodruk wybranych fragmentów tej książki ukazał się w 2005 roku (Obrębski 2005a).

${ }^{21} \mathrm{~W}$ spuściźnie archiwalnej Obrębskiego nie ma angielskich tekstów na temat magii na Poreczu; są jedynie szczupłe notatki konspektowe. Zachowane opracowania angielskie dotyczą zagadnień rodziny, małżeństwa oraz dekonstrukcji etnologicznych mitów dotyczących południowych Słowian. 
Macedońskie Trobriandy. Józef Obrębski i pierwsze badania...

Czarownictwo było opracowywane w terenie i potem pod świeżymi jeszcze reminiscencjami mojego treningu u Pana Profesora i metodycznie i teoretycznie wywodzi się właściwie z Coral Gardens. (...) Pracę nad Czarownictwem podjąłem b[ardzo] niedawno i z racji stałych wyjazdów w teren i bieżących robót poleskich $^{22}$ posuwałem ją naprzód b[ardzo] nierównymi i dorywczymi skokami. (...) Właśnie w sprawie tej pracy chciałem się zwrócić do Pana Profesora z zapytaniem, czy można by było prosić Pana Profesora o wstęp do tej książki, o ile oczywiście uzna ją Pan Profesor za godną tego. Byłbym szczerze szczęśliwy, gdyby pierwsza moja książka etnologiczna była zaszczycona tym wyróżnieniem i tym znakiem szkoły i kierunku. Z przykrością jednak muszę uprzedzić, że temu niedoszłemu jeszcze Czarownictwu daleko jest nie tylko do Coral Gardens, które stanowiły dlań wzór niedościgniony i niemożliwy do urzeczywistnienia, ale nawet do Sorcerers of Dobu ${ }^{23}$. Choć to, mam nadzieję, może być położone częściowo na karb terenu (list Obrębskiego do Malinowskiego, 24.01.1935, LSE).

Kolejna monografia, Skandal we wsi ${ }^{24}$, wyrastająca ze studiów Obrębskiego nad organizacją rodzinną, poświęcona jest w szczególności instytucjom odkupu za żonę i małżeństwa przez ucieczkę, a także niedopasowaniu małżeńskiemu. Wreszcie ostatnia - Mit i rzeczywistość u Słowian Poludniowych - to studium dekonstruujące rozpowszechnione w etnologii mity, które orientalizowały południowosłowiańskich chłopów (m.in. mit o sprzedawaniu żon, o zabijaniu starców czy o miłości kazirodczej). O tym projekcie pisał Obrębski Moszyńskiemu, że jest to

praca, zamierzona nie jako terenowa, ale jako ogólnobałkańska teoretyczna. (...) Tezą teoretyczną jest, że mity te mylnie pojmowane są bądź jako tradycja zamierzchłej i zaginionej kultury (...), bądź (...) jako świadectwo narodowej lub państwowej świadomości włościan macedońskich (...). Funkcjonują one w obecnej aktualnej strukturze społecznej bądź jako sankcja istniejącego stanu rzeczy, bądź jako nakaz moralny w kompleksie stosunków socjalnych, właściwych dla

${ }^{22}$ Obrębski odnosi się tu do swojej ekspedycji terenowej na białorusko-ukraińskim Polesiu, którą prowadził w latach 1934-1936 (por.: Obrębski 2007).

${ }^{23}$ Sorcerers of Dobu - wydana w roku 1932 z przedmową Malinowskiego monografia jego ucznia, Reo Fortune'a, poświęcona nowogwinejskiemu czarownictwu w kontekście struktury społecznej.

${ }^{24}$ Pierwodruk fragmentu tej monografii (czy raczej wariantu jednego z jej 5 rozdziałów, opracowanego jako niezależna opowieść etnograficzna), zatytułowany przez autora tak samo jak planowana książka, ukazał się w 2005 roku (Obrębski 2005c). 
kultury bałkańskiej. Tak więc cała praca rozpada się na dwa działy: teoretyczno-polemiczny, gdzie druzgotane są dotychczasowe błędy etnograficzne, i konstruktywny, gdzie dla każdego z mitów wskazany jest jego właściwy kontekst socjalny. To oczywiście obejmuje analizę szeregu dziedzin życia (list Obrębskiego do Moszyńskiego, 4.04.1933, IAiEK UJ).

Jednym z analizowanych przez Obrębskiego mitów z tej grupy był pochodzący spoza terenu macedońskiego, wpisujący się w szerszy kontekst słowiański i bałkański mit o mężczyźnie w połogu - związany „ze strukturą rodziny: jej jednostronną patrylinealną filiacją przy bilateralnej organizacji” (list Obrębskiego do Moszyńskiego, 4.04.1933, IAiEK UJ). Skontekstualizowana antropologiczna interpretacja tego mitu ujrzała światło dzienne jako Family Organisation Among Slavs as Reflected in the Custom of Couvade - rozprawa doktorska Obrębskiego (Obrębski 1933). Choć pracował później nad przygotowaniem jej do publikacji - miała się ukazać, podobnie jak książki innych uczniów Malinowskiego, z jego wstępem ${ }^{25}$ - nie zdołał tego projektu doprowadzić do końca.

Macedońskie materiały i pisma Obrębskiego znajdują się obecnie w archiwum University of Massachussetts w Amherst, które po jego śmierci w Nowym Jorku w 1967 roku przyjęło spuściznę uczonego ${ }^{26}$.

${ }^{25}$ „Swego czasu wyraził Pan Profesor życzenie napisania wstępu do Kuwady. Żałuję bardzo, że dotychczas nie mogłem wykorzystać tej propozycji, podobnie jak i poparcia, które Pan Profesor zaofiarował przy ewentualnym opublikowaniu tej pracy. Po otrzymaniu przeszło już rok temu listu Pana Profesora w tej sprawie łudziłem się jeszcze długi czas, że uda mi się sprawy moje ułożyć w ten sposób, by móc wreszcie tę Kuwadę wykończyć i przysłać. Pracować nad nią mogłem jednak tylko b[ardzo] dorywczo i b[ardzo] nieregularnie, tak że zaledwie parę pierwszych rozdziałów zdołałem jako tako przygotować. Było to wszystko razem b[ardzo] zniechęcające. Tym bardziej że widziałem, że praca ta wymaga b[ardzo] gruntownej przeróbki (...). Poza tym czekają jeszcze Kuwadę wykończenia bibliograficzno-odnośnikowe, których nie mogę dokonać na miejscu. W tym związku planowałem stale dla zakończenia tej pracy wyjazd do Londynu przynajmniej na kilka tygodni; okazuje się jednak, że oceniałem swoje możliwości zbyt optymistycznie. Być może uda mi się ten plan zrealizować w niedalekiej przyszłości. Pragnąłbym tego tym bardziej, że odczuwam wielką potrzebę odetchnięcia atmosferą seminarium Pana Profesora i obawiam się, że bez tej wędrówki do Mekki etnologicznej moja praca i mój rozwój intelektualny stale będą traciły" (list Obrębskiego do Malinowskiego, 24.01.1935, LSE).

${ }^{26}$ Spuścizna ta została opracowana jako „Obrebski Collection”;

http://scua.library.umass.edu/umarmot/obrebski-jozef/ 
Macedońskie Trobriandy. Józef Obrębski i pierwsze badania...

Jest to, poza fotografiami, ogółem około półtora tysiąca stron rękopisów i maszynopisów pisanych po polsku, macedońsku (w serbskim zapisie cyrylickim lub w transkrypcji łacińskiej) oraz angielsku. Spośród tego ogromnego dorobku za życia Obrębskiego ukazały się drukiem tylko dwa artykuły: oba przed II wojną światową w popularnonaukowym „Kuryerze Literacko-Naukowym". Były to Czarna magia w Macedonii (1934) i System religijny ludu macedońskiego (1936) (Obrębski 1934, 1936). Wkrótce po śmierci uczonego zredagowano też i publikowano w kolejnych edycjach jego tekst Social Structure and Ritual in a Macedonian Village ${ }^{27}$, wygłoszony pierwotnie jako referat na Annual Meeting of American Anthropological Association w 1961 roku w Filadelfii. W tym kontekście należy też wymienić wygłoszony tuż przed wybuchem wojny referat metodologiczny Obrębskiego, O metodzie funkcjonalnej Bronisława Malinowskiego, niedawno opublikowany dzięki zachowanemu zapisowi ze stenogramu (Obrębski 2004).

\section{Relacje między płciami na Poreczu jako „dwudział strukturalny”}

Badanie organizacji rodzinnej i społecznej oraz systemu pokrewieństwa wraz z seksualnością w ich dynamicznej syntezie z systemem wierzeniowym i praktykami rytualnymi, także tymi aspołecznymi, sprawowanymi w ukryciu, doprowadziło Obrębskiego do precyzyjnego zrozumienia lokalnego systemu społeczno-kulturowego i do wielu odkrywczych interpretacji. Przede wszystkim jest to bardzo konsekwentna interpretacja rzeczywistości społecznej Porecza w kategoriach, które dziś ujmujemy w teoriach gender $^{28}$. Obrębski mówi o specyficznym dla poreckiej struktury społecznej „,dwudziale strukturalnym” - czyli ,podziale społeczności wiejskiej na różnoprawne i różnie społecznie sytuowane ugrupowania mężczyzn i kobiet”.

${ }^{27}$ Pierwodruk: Ritual and Social Structure in a Macedonian Village, Northeast Meeting, American Association for the Advancement of Slavic Studies, Boston University, 1969, ed. by B. Halpern, 21s. Najnowsza, zrewidowana edycja: Obrębski 2006. Pierwszy przekład polski, zatytułowany Obrzędowa i społeczna struktura wsi macedońskiej: Obrębski 1972; thumaczenie zrewidowane i poprawione: Obrębski 2005d.

${ }^{28}$ Obrębski, co oczywiste, nie mógł w latach 30. XX wieku operować kategorią gender - pojęcie to wprowadził do obiegu John Money dopiero w 1955 roku. 
Cała struktura społeczeństwa macedońskiego wspiera się na podziale męsko-kobiecym - pisał. Zróżnicowanie to nie jest wyłącznie kwestią spekulacji biologicznej. Jest ono przepojone istotną treścią społeczną, przenika wszelkie dziedziny życia: organizację społeczną, gospodarkę, prawo, obyczaj moralny, religię i sztukę. Nie ma ani jednej grupy społecznej, ani jednej instytucji, której charakter nie byłby nacechowany tym podziałem. W imię tego zróżnicowania pomiędzy mężczyzn i kobiety rozdzielane są różnorakie funkcje, różnorakie prerogatywy i obowiązki, różnorakie wzory zachowania się i działania - w ścisłej grupie rodzinnej, w gromadzie wiejskiej i na arenie publicznej. Podział ten determinuje [odmienność] zadań życiowych i [odmienność] kariery życiowej (...) mężczyzny [i] kobiety. Zwyczaj, prawo i praktyka zakreśla mężczyźnie i kobiecie inne drogi życiowe (OC: Czarna magia).

Co więcej, wskazuje na determinowaną przez reguły patriarchatu społeczną nierówność obu płci:

Mężczyźni tworzą klasę uprzywilejowaną, władającą ziemią i stadami, dysponującą bogactwem, decydującą o sprawach wsi, domu, rodziny i podwładnych im kobiet. Kobiety są im podporządkowane i niższość ich stanowiska społecznego ujawnia się na każdym kroku: w ograniczeniach ich praw posiadania, w eliminacji z rad rodzinnych i wiejskich, w obciążeniu ich pracą, ograniczeniach etykiety i zwyczaju, wreszcie w specyficznej feminofobii Macedończyka, przypisującego naturze kobiecej zło, przewrotność i przestępczość (OC: Czarna magia).

Wskazując i analizując społeczny charakter konstruowania ról i relacji płciowych, Obrębski jest daleki od esencjalizmu. Jego „dwudział strukturalny" ma konsekwentnie wymiar konstruktywistyczny, jest pochodną nie „naturalnych”, biologicznych, lecz społeczno-kulturowych „,czynników, które ustanawiają i podtrzymują w społeczeństwie wschodnioeuropejskim społeczny podział na kobiety i mężczyzn" (Obrębski 1933: 53) ${ }^{29}$. Nie koniec na tym: nie redukuje bynajmniej owego podziału do męskiej dominacji i kobiecego podporządkowania (które analizował w kontekście społeczno-ekonomicznym oraz symbolicznym, dekonstruując ,ideologię wyższości mężczyzn nad kobietami” (Obrębski 1933: 99)). Przestrzega ,przed stosowaniem jakichkolwiek absolutnych kryteriów oceniania

${ }^{29}$ Wszystkie cytowane fragmenty Kuwady, o ile nie zaznaczono inaczej, w tłumaczeniu Jakuba Ozimka. 
Macedońskie Trobriandy. Józef Obrębski i pierwsze badania...

pozycji kobiet, ich «niższości» bądź «wyższości», w sytuacji, gdy różne aspekty życia społecznego dostarczają na takie pytanie różnych odpowiedzi" (Obrębski 1933: 22). Pokazuje, jak elastyczna i niekonsekwentna potrafi być, zależnie od okoliczności, dynamika męsko-kobiecej nierówności. Pieczołowicie wydobywa na światło dzienne niespójności, sprzeczności i paradoksy, wskazujące te aspekty relacji między płciami, w których bądź obie mają równoprawną pozycję i przywileje (jak najstarsze pokolenie grupy domowej: gospodyni-matka i ojciec-gospodarz), bądź też kobietom przypada rola dominująca. Dużo miejsca poświęca analizom tego ostatniego przypadku. Zajmuje się małżeństwem matrylokalnym, w którym to żona-gospodarz pełni społeczną funkcję mężczyzny, zaś mąż-prymak (zięć mieszkający u teściów) - podporządkowanej kobiety. Szczegółowo przedstawia nadrzędną i sprawczą rolę kobiet w rytuałach magiczno-religijnych.

Analizując szczególną pozycję, jaką w tym genderowym dwudziale zajmuje antyspołeczne czarownictwo, uprawiane przez zajmujące niższą pozycją społeczną kobiety, Obrębski dowodzi, że dominująca rola kobiet w życiu obrzędowym społeczności jest konstytutywną cechą badanej kultury. Cechą, bez której cały system społeczno-kulturowy utraciłby równowagę. Przytoczmy konkluzję jego artykułu Social Structure and Ritual in a Macedonian Village:

Przywileje, prawa i obowiązki przyznawane kobietom w sferze działań rytualnych rekompensują upośledzenie statusu, jakie dotyka je w życiu świeckim. (...) W planie świeckim fukcjonuje system nadrzędności i podporządkowania, system kręgów solidarności, sytuujący mężczyzn ponad kobietami i kobiety poniżej mężczyzn. Poziom rytualny otwiera drogę stosunkom społecznym innego typu: opartym na lojalności osobistej i rodzinnej, na uczuciu przywiązania i na współpracy. Zasady patrylinii sprawiają, że wspólnota świecka składa się z mężczyzn i „dodatków” do nich. Dzieli swoich członków na tubylców i obcych, mężczyzn i kobiety. Wywyższa mężczyzn i ich potomków i podporządkowuje kobiety mężczyznom, siostry braciom, a nawet matki synom. Wspólnota religijna przywraca równowagę. Obejmuje wszystkich: tubylców i obcych, mężczyzn i kobiety, dzieci i dorosłych, bogatych i biednych, żywych i umarłych. Wspólnota świecka opiera się na unilateralnej, patriarchalnej podstawie. Wspólnota religijna jest co najmniej bilateralna, o ile nie omnilateralna; jest egalitarna i inkluzywna (OC: Social Structure; thum. A. Engelking). 
Konstruktywistyczne ujęcie Obrębskiego ukazuje relacje genderowe (w jego terminologii: „społeczny podział na kobiety i mężczyzn”) jako zanurzone w urządzeniach społecznych, które przydają im różnorodnych funkcji i znaczeń. Jego „dwudział strukturalny”, nieredukowalny czy to do seksualności, czy do zapewnienia następstwa pokoleń, jest dynamicznie, w zależności od kontekstu, kształtowany przez formatowane regułami patriarchatu czynniki historyczne, ekonomiczne, kulturowe i symboliczne. To elastyczny mechanizm stanowiący fundament i zasadniczą oś konstrukcyjną całego systemu społeczno-kulturowego. I zarazem mechanizm gwarantujący jego pełnię, spójność, dynamikę i kontynuację.

\section{Empiryzm i antyesencjalizm monografii macedońskich}

Obrębski, wzorem Malinowskiego, pozostawał w sporze z „etnologią starego typu" (OC: Giaurowie). Dekonstruował ugruntowane w antropologii ewolucjonistyczne i dyfuzjonistyczne mity i esencjalizmy, w tym konstytuujący etnografię/etnologię europejską, także polską, romantyczny mit wsi jako skarbnicy tworzących rdzeń kultury narodowej archaizmów. Jego krytyka była zakorzeniona tyleż w teorii (przy czym czerpał nie tylko z funkcjonalizmu Malinowskiego), co w empirii - w bogatym etnograficznym doświadczeniu osobistym, także tym wcześniejszym, sprzed „terenówki” w Macedonii ${ }^{30}$.

Sądzę, że w dużym stopniu właśnie dlatego, że doskonale znał wieś wschodnio- i południowoeuropejską, że czuł się wśród jej mieszkańców swojsko i kompetentnie, że miał łatwość funkcjonowania w terenie, potrafił patrzeć na badaną rzeczywistość nie przez okulary ideologii i uprzedzeń, ale znacznie bardziej realistycznie i krytycznie. Choć interesowała go (re)konstrukcja tego, co w kulturze systemowe, dostrzegał i analizował m.in.: ,to, co tak często było [lekceważone i] pomijane w opisie życia wsi: podział klasowy [i] klasowe nierówności, indywidualizm rodzinny (...), obecność konfliktów i tarć, wynikających ze sprzeczności interesów i z egoizmów [poszczególnych] rodzin - jednym słowem to wszystko, co (...) podważa mit społecznej jednorodności wsi”

${ }^{30}$ Doświadczenie terenowe Obrębski zdobywał od początku studiów etnograficznych, prowadząc badania w wielu miejscach w Polsce. W latach 1927 i 1928 ogółem przez pięć miesięcy pracował w terenie w Besarabii, Dobrudży, Bułgarii, Turcji europejskiej, wschodniej Macedonii, Kosowie, Serbii i Chorwacji. 
Macedońskie Trobriandy. Józef Obrębski i pierwsze badania...

(OC: Giaurowie). W swoich opisach i interpretacjach niezmiennie zdawał sprawę z zaobserwowanych faktów, dążył do poznania „,rzeczywistości i dynamiki życia wiejskiego" (OC: Giaurowie) $)^{31}$. W centrum jego zainteresowań pozostawał bowiem żywy, konkretny człowiek (nie „typ”!), z jego doświadczeniem życiowym, potrzebami, emocjami, sprawczością, systemem wartości i przekonań. Obrębski był humanistą i zarazem myślicielem o lewicowej wrażliwości. Dlatego też patrzenie na badaną rzeczywistość „,z punktu widzenia tubylca” stanowiło dla niego dyrektywę pozadyskusyjną.

W pracach macedońskich, które adresował przede wszystkim do odbiorców z zachodniej Europy, budował Obrębski swój autorytet etnograficzny poprzez autowizerunek badacza bliskiego tubylcom, wręcz jednego spośród nich: Słowianina wśród Słowian. Podkreślał swoją pochodzącą z autopsji znajomość wschodnio- i południowoeuropejskich chłopów, pisał o łączących go z nimi osobistych więzach przyjaźni ${ }^{32}$. I choć w rzeczywistości od macedońskich górali dzieliło go bardzo wiele - przede

${ }^{31} \mathrm{O}$ etnologicznych romantyzacjach i mitologizacjach rzeczywistości wiejskiej pisał: „Fałszywość tej wizji [wypływa] nie tyle z doktrynerstwa teoretycznego, ile z niedostatku obserwacji empirycznej, z niewyciągania ze spostrzeżeń - nie dość cenionych i uważanych za mało ważkie - właściwych wniosków. Przeciętny etnolog starego typu, udający się w teren z przygotowanym zawczasu kwestionariuszem, nie zainteresowany rzeczywistością i dynamiką życia wiejskiego, podchodzi do obiektu swych studiów ze szczególną postawą. Wieśniacy, mający stać się przedmiotem jego studiów, to dla niego nie członkowie społeczeństwa miejscowego, członkowie instytucji, grup itp., które składają się na to społeczeństwo, nie żywi ludzie, których trzeba poznać i obserwować, ale ankietanci, informatorzy - dobrzy i źli. (...) Indywidualizuje on społeczeństwo badane w tych kategoriach i stawia sobie za zadanie, by zestawić - z informacji uzyskanych przez indagacje - pewien wzór zwyczajowy, który traktuje jako typowy czy charakterystyczny, nie troszcząc się już wiele o to, czy i w jakim stopniu jest on realizowany i przez kogo" (OC: Giaurowie).

32 Jak we wstępie do Kuwady: „Jestem, było nie było, Słowianinem, urodzonym i wychowanym w najbardziej archaicznych i pierwotnych rejonach Europy. Mam więc wrodzoną znajomość moich stron rodzinnych. Mam, co więcej, osobiste doświadczenie obcowania z moimi chłopskimi ziomkami - doświadczenie, które zdobyłem nie tylko dzięki antropologicznym badaniom terenowym w Polsce, Białorusi, Ukrainie i w krajach bałkańskich, lecz przede wszystkim dzięki bliskim przyjaźniom z wieloma tubylcami z tych krajów. (...) Jeżeli czytelnik zaufa mojemu doświadczeniu i przyjmie mnie za przewodnika, pomoże nam to podejść do problemu kuwady bez zahamowań wynikających z przyrodzonego zachodniemu Europejczykowi przekonania o wyższości jego racjonalnego światopoglądu i cywilizowanych zwyczajów nad niezrozumiałymi pojęciami i dziwacznymi obyczajami dzikich” (Obrębski 1933: 5; tłum. A. Engelking). 
wszystkim pozycja społeczna ze wszystkimi atrybutami różnicy klasowej (dla Poreczan był człowiekiem, który pochodził z miasta, pisał i czytał, dysponował zasobami finansowymi) - efekty przeprowadzonych przez niego badań pokazują, że jego konstatacja ,przestałem być cudzoziemcem - zacząłem być swoim człowiekiem" (Obrębski 2005c: 70) nie była gołosłowna. Potwierdzeniem tego konstruktywnego przymierza terenowego zawartego przez antropologa $\mathrm{z}$ badaną społecznością były dwa powroty do Wołcza, jakie po śmierci Obrębskiego przedsięwzięła jego żona, Tamara Obrębska (w 1969 i 1971 roku). Dziś potwierdzają je stale funkcjonująca w obiegu ustnym na Poreczu, już zmitologizowana, pamięć o Josifie, opublikowane przez jednego z wołczan wspomnienia o nim (Veselinovski 2002), nazwa głównej ulicy Samokova, największej miejscowości Górnego Porecza: ulica Josif Obrembski, wreszcie stojący na centralnym placu tego miasteczka marmurowy pomnik Obrębskiego - jedyny chyba na świecie pomnik antropologa; pomnika nie ma nawet Malinowski ${ }^{33}$.

W pismach Obrębskiego obecny jest otwarty sprzeciw wobec etnocentryzmu. Ze złośliwą niejednokrotnie ironią punktował charakterystyczne dla Zachodu deprecjonowanie chłopów ze wschodu kontynentu poprzez ich orientalizację.

Te wschodnioeuropejskie ludy patriarchalne - zauważał - (...) to pracowici rolnicy i wprawni hodowcy zwierząt i nawet jeśli rzeczywiście zdarza im się odprawiać różnorakie ceremonie odmienne od nabożeństw kościoła anglikańskiego czy działalności Armii Zbawienia, w życiu codziennym nie są być może dużo bardziej zabobonni niż, powiedzmy, zachodnioeuropejscy politycy czy oficerowie lotnictwa. (...) [C]hoć nie należą oni do narodów z awangardy cywilizacji zachodnioeuropejskiej, nieuprawnione (...) byłoby przypisywanie im indolencji umysłowej i nadmiernego przywiązania do tradycji. Opinii takiej w pewnym stopniu przeczy też rewolucja bolszewicka (Obrębski 1933: 4).

Obrębski był badaczem współczesności. Horyzont interpretacyjny jego analiz wyznaczała perspektywa globalna i kontekst społeczno-kulturowy, jakim były procesy modernizacyjne.

${ }^{33}$ Więcej na temat pamięci o Obrębskim na Poreczu, zob. Bielenin-Lenczowska, Engelking 2015. 
Macedońskie Trobriandy. Józef Obrębski i pierwsze badania...

Na arenę dziejową świata - pisał - wkraczają niedostrzegane dotychczas na niej postaci chłopa wschodnioeuropejskiego i jego braci znad Gangesu, znad Rzeki Żółtej i znad Nilu. Powstawanie nowoczesnych społeczeństw (...) opartych o nowo formującą się i szybko krzepnącą warstwę chłopską, (...) jest jednym z najdonioślejszych zjawisk i procesów współczesnej historii. (...) Poznając którąkolwiek ze stron życia małej, archaicznej społeczności rolniczej Europy, Azji, Afryki czy Ameryki, dotykamy substratu stającej się cywilizacji przyszłości (OC: Giaurowie).

\section{Projekt niedopełniony}

Pozostaje zadać pytanie o to, dlaczego dorobek macedoński Józefa Obrębskiego i wiedza o tym dorobku prawie nie funkcjonują w dyskursie antropologicznym34. Jest to pytanie tym bardziej ważkie, że gdyby w latach 30. XX wieku opublikował on, jak zamierzał, przynajmniej Kuwadę i Czarownictwo ze wstępami Malinowskiego, nie mówiąc o utraconej w czasie wojny monografii macedońskiego systemu magiczno-religijnego, przekaz tych książek nie pozostałby bez wpływu na dalszy rozwój antropologii. Początek antropologii społeczności chłopskich musielibyśmy przesunąć z lat 50. do lat 30. XX wieku ${ }^{35}$. Obrębski funkcjonowałby obok Malinowskiego i Mead jako odkrywczy antycypator teorii gender. Wreszcie, mielibyśmy nie tylko inny obraz wpływu funkcjonalizmu na badania antropologiczne podejmowane w Europie, lecz także same te badania po zintegrowaniu dokonań Obrębskiego najprawdopodobniej wyglądałyby odmiennie.

34 Wyjątek stanowią macedoniści - przede wszystkim antropolodzy oraz folkloryści macedońscy i polscy, którzy poza artykułami Obrębskiego opublikowanymi po polsku i angielsku korzystają z wyboru jego prac i materiałów wydanego w przekładzie macedońskim (Obrembski 2001a, 2001b, 2002). W tym środowisku powstają zarówno teksty o Obrębskim i jego badaniach (m.in. Bielenin-Lenczowska, Engelking, 2015, Georgievski 2014, Risteski 2011), jak i, co najistotniejsze, prace inspirowane jego dokonaniami (m. in. Lubaś 2011, Rękas 2018, Rękas, Lučeska, 2015). Ukazały się też tomy zbiorowe stanowiące pokłosie przedsięwzięć poświęconych Obrębskiemu (Vrażinovski 2002, Vrażinovski, Engelking, Halpern 2003, Vrażinovski, Karadżoski, Jovanovska-Rizoska 2006, Lucheska, Dimoski 2013, Bielenin-Lenczowska 2015).

35 „Chociaż chłopi do niedawna stanowili najważniejszą część populacji światowej, dopiero w latach 50. stali się odrębnym przedmiotem badań w ramach antropologii, a największym zainteresowaniem badaczy cieszyli się pod koniec lat 60 . i na początku lat 70. XX wieku" (Spencer 2008: 155). 
Po powrocie swego ucznia z Macedonii Malinowski sformułował dla Fundacji Rockefellera opinię następującej treści:

Sprawa Obrębskiego jest, jak Pan to ujmuje, „dosyć niejasna”. Nie ma żadnej wątpliwości, że należy on do najzdolniejszych wśród młodzieży etnologicznej. Jest dobrym pracownikiem, oryginalnym, przenikliwym, efektywnym. Z pewnością ma iskrę geniuszu. Przy tym wszystkim nie jest pewne, czy faktycznie wysunie się na czoło. $Z$ tego, co wiem, ma w papierach co najmniej dwa manuskrypty niemal gotowe do publikacji, które, obawiam się, nigdy nie ujrzą światła dziennego. Skrajny perfekcjonizm; sam cierpię na tę słowiańską chorobę (i wiele innych). Niech Pan będzie w stosunku do Obrębskiego bardzo wyrozumiały. Nie tracę nadziei, że znajdzie się w pierwszym szeregu (list Malinowskiego do Kittredge'a, 22.10.1933, LSE; tłum. A. Engelking).

Gdyby Obrębski pozostał w 1934 roku w Londynie i nadal współpracował z Malinowskim - czyli odpowiedział pozytywnie na propozycję, którą wtedy od niego otrzymał ${ }^{36}$ - może jego perfekcjonizm byłby lepiej kontrolowany i Kuwada oraz późniejsze monografie macedońskie ujrzałyby światło dzienne. Propozycji tej jednak nie przyjął i wrócił do Polski, gdzie nie czekała na niego kariera akademicka w klasycznym rozumieniu (jako zatrudnienie na państwowym uniwersytecie), mimo że posiadał najwyższej próby kompetencje merytoryczne. Kompetencje bez porównania wyższe niż polscy koledzy-etnolodzy z jego pokolenia.

Po powrocie do kraju przez dwa i pół roku Obrębski nie miał stałej pracy, jego sytuacja zawodowa i finansowa była niestabilna. Związał się z Instytutem Badań Spraw Narodowościowych - eksperckim think-tankiem zajmującym się problematyką mniejszości narodowych w Polsce i na zlecenie instytucji rządowej, Komisji Naukowych Badań Ziem Wschodnich (por. Engelking 2007b, 2019), realizował projekt badawczy: badania terenowe na Polesiu, skupione wokół procesów modernizacyjnych,

${ }^{36} \mathrm{O}$ tej propozycji Malinowskiego powiedziała mi (w osobistej rozmowie w 1994 roku) siostra Józefa, prof. Antonina Obrębska-Jabłońska. Jej potwierdzenie odnalazłam później w jednym z listów otrzymanych przez Obrębskiego od matki, gdy mieszkał już w Nowym Jorku: „Nie zapominam tego listu Malinowskiego, gdy prof. Malinowski pisał do mnie, że ja jako matka, czy mogłabym pozwolić, abyś mógł z nim współpracować przez czas dłuższy. Gdy napisałam Tobie o liście Malinowskiego do mnie, odpisałeś mi, że studiować za granicą można, ale pracować należy się w Polsce i tylko dla Polski” (list Marii Obrębskiej do Obrębskiego, 27.04.1957, OC). 
Macedońskie Trobriandy. Józef Obrębski i pierwsze badania...

w tym narodotwórczych, wsi wschodnioeuropejskiej ${ }^{37}$. Stabilizację osiągnął dopiero pod koniec 1936 roku, wraz z objęciem funkcji wicedyrektora $\mathrm{w}$ nowo powołanej, zorientowanej socjologicznie instytucji badawczej - Państwowym Instytucie Kultury Wsi ${ }^{38}$. Łatwo zgadnąć, że w życiu wypełnionym nie tylko wielomiesięczną ekspedycją terenową oraz zadaniami naukowymi i organizacyjnymi w Instytucie, ale też pracami dorywczymi (wykłady w różnych instytucjach, prace przekładowe, redakcyjne i in.), nie starczyło mu zasobów na finalizację monografii macedońskich. W tym okresie sporo pisał i publikował, ale Czarownictwu i pozostałym książkom przyszło czekać na swój czas.

W 1939 roku rozpoczęła się wojna, która w efekcie przyniosła Polsce zmianę systemu politycznego i jako jedną z konsekwencji tej zmiany - głęboką rekonfigurację w instytucjonalnym i merytorycznym polu nauki. Obrębski opuścił kraj. W Stanach Zjednoczonych, gdzie mieszkał od 1948 roku, nie zdobył już takiej pozycji w środowisku akademickim, jaką miał wyjeżdżając z Polski ${ }^{39}$. W kolejnych latach, które mu pozostały do przedwczesnej śmierci w wieku 62 lat, kilka razy powracał do pracy nad materiałami macedońskimi. Do Nowego Jorku sprowadził z Warszawy całą swoją dokumentację terenową. Zaczął pracować nad angielską monografią The Giaours of Macedonia. Zamierzał ukończyć ją na emeryturze.

\section{Konkluzja}

Stopniowe opracowywanie i publikowanie dorobku Józefa Obrębskiego, nieogłoszonego drukiem za życia autora, ma miejsce od około

${ }^{37}$ Badania te zaowocowały serią 4 artykułów opublikowanych przez Obrębskiego w 1936 roku, w których m.in. zaprezentował nowatorską, antyesencjalistyczną teorię grup i granic etnicznych. 30 lat przed Barthem i Andersonem konceptualizował te fenomeny jako „twory wyobrażeniowe” i opisywał konfigurację grup etnicznych jako system opozycji między wizerunkami „obcych” i ,swoich”. Por. zwłaszcza Obrębski 2005b (1936).

${ }^{38}$ Szczegółowo o życiu zawodowym i powiązaniach środowiskowych Obrębskiego w okresie 1934-1946 pisałam w Engelking 2006.

${ }^{39}$ Wyjechał jako doktor habilitowany etnologii, kierownik Katedry Etnologii w Instytucie Socjologicznym Uniwersytetu Łódzkiego. 
dwóch dekad ${ }^{40}$. Jest to realizacja zbiorowej woli polskiego środowiska etnologicznego, formułowanej już przed 40 laty przez Annę Kutrzebę-Pojnarową. Pisała ona:

Obrębski nie musi być reklamowany. (...) Ale jego prace pozostają w rękopisach, a artykuły są trudno dostępne. Odkrywane co pewien czas przez młodsze pokolenia etnografów, udostępniane również poza krajem, uczestniczą we współczesnym rozwoju nauki przyswajane jedynie w małym gronie specjalistów. Warto stworzyć dla nich należne im miejsce w bibliotece klasyków etnologii polskiej (która powinna przecież kiedyś powstać niezależnie od biblioteki europejskiej i pozaeuropejskiej socjologii i antropologii kulturowej i społecznej). Wobec braku tej biblioteki zbyt łatwo na ogół szukamy wzorów obcych, nie doceniając ciągłości, jak też różnorodności spojrzenia i metod naszej własnej nauki (Kutrzeba-Pojnarowa 1979: 72).

Planowana w bliskiej przyszłości publikacja macedońskich prac uczonego - jego „trobriandzkiej” próby holistycznego opisu wsi południowoeuropejskiej, w którego centrum stoją żywi, konkretni ludzie - pociągnie za sobą konieczność przebudowania opowieści o historii naszej dyscypliny w Polsce i w Europie. Mam także nadzieję, że wprowadzi ostatecznie Józefa Obrębskiego do pierwszego szeregu antropologów europejskich. Nie tylko jako figurę historyczną, ale także żywą, która stale inspiruje i pobudza do antropologicznej aktywności i refleksji.

\section{BIBLIOGRAFIA}

Bielenin-Lenczowska, K. (red.) (2015). Anthropology of continuity and change. Macedonian Poreče 80 years after Józef Obrębski 's work. Warszawa: Instytut Slawistyki PAN.

Bielenin-Lenczowska, K., Engelking, A. (2015). Józef Obrębski’s Poreče. An ethnographic revisit. W: K. Bielenin-Lenczowska (red.). Anthropology of continuity and change. Macedonian Poreče 80 years after Jozef Obrebski’s work, s. 9-29. Warszawa: Instytut Slawistyki PAN.

${ }^{40}$ Jestem redaktorką naukową dzieł zebranych Józefa Obrębskiego. Pierwszy tom, zawierający prace dotyczące Polesia, ukazał się w 2007 roku (Obrębski 2007). Tom drugi, obecnie w przygotowaniu, zawiera prace dotyczące Macedonii. W projekcie są jeszcze dwa kolejne tomy. Wśród przedsięwzięć wprowadzających Obrębskiego post mortem do antropologicznego obiegu należy jeszcze wymienić macedońską edycję jego pism (Obrembski 2001a, 2001b, 2002) oraz amerykańskie opracowanie wykładów, które wygłosił w 1946 roku w Oxfordzie (Obrebski 1976). 
Macedońskie Trobriandy. Józef Obrębski i pierwsze badania...

Engelking, A. (2004). Obrębski o Malinowskim. Z dziejów recepcji funkcjonalizmu w Polsce. Studia Socjologiczne, 173 (2), 17-34.

Engelking, A. (2006). Józef Obrębski - etnolog i socjolog warszawski. Sprawy Narodowościowe, 29, 91-106.

Engelking, A. (2007a). Józef Obrębski (1905-1967). W: E. Fryś-Pietraszkowa, A. Spiss (red.). Etnografowie i ludoznawcy polscy. Sylwetki, szkice biograficzne. T. 2, s. 226-233. Wrocław-Kraków: Polskie Towarzystwo Ludoznawcze.

Engelking, A. (2007b). Polesie Józefa Obrębskiego. W: J. Obrębski. Polesie. Studia etnosocjologiczne (red. A. Engelking). T. 1, s. 9-32. Warszawa: Oficyna Naukowa.

Engelking, A. (2012). Kazimierz Moszyński i Józef Obrębski: nauczyciel i uczeń. Lud, 96, 139-156.

Engelking, A. (2018). Krakowski projekt słowianoznawstwa zintegrowanego. Wizja, realizacje, kontynuacje. W: E. Drzewiecka, E. Wróblewska-Trochimiuk (red.). Niekonwencjonalne historie instytucji slawistycznych. Warszawa: Instytut Slawistyki PAN [w druku].

Engelking, A. (2019). Uczony w konfrontacji z polityką państwa. Przypadek Józefa Obrębskiego, badacza Polesia w II Rzeczypospolitej. Sprawy Narodowościowe [w druku].

Flis, M., Paluch, A. K. (red.) (1985). Antropologia społeczna Bronisława Malinowskiego. Warszawa: PWN.

Georgievski, P. T. (2014). Karakteristike etnografskog istraživanja sela u Poreču tridesetih godina od polskog sociologa J. Obrembskog. W: D. ђorđević (red.). Biti sociolog sela. Spomenica நure Stefanovića, s. 97-118. Nowi Sad: Prometej.

Kuper, A. (1987). Między charyzma i rutyna. Antropologia brytyjska 1922-1982 (przeł. K. Kaniowska). Łódź: Wydawnictwo Łódzkie.

Kutrzeba-Pojnarowa, A. (1979). Wkład Józefa Obrębskiego w badanie procesów etnicznych. Etnografia Polska, 23 (2), 72-82.

Lubaś, M. (2011). Różnowiercy. Wspótistnienie międzyreligijne w zachodniomacedońskiej wsi. Studium z zakresu antropologii społeczno-kulturowej. Kraków: Nomos.

Lučeska, E., Dimoski, Z. (red.) (2013). 105 godini od ragianieto na Jozef Obrembski. 105 years from the birth of Józef Obrębski. Prilep - Poznań: Institut za Staroslovenska Kultura, Instytut Filologii Słowiańskiej UAM.

Malinowski, B. (1938a). Prawo i zwyczaj (przeł. J. Obrębski). Przegląd Socjologiczny, 6 (1-2), 1-50. 
Malinowski, B. (1938b). Zwyczaj i zbrodnia w społeczności dzikich (przeł. J. Obrębski). Przegląd Socjologiczny, 6 (3-4), 307-380.

Malinowski, B. (1986). Ogrody koralowe i ich magia. Studium metod uprawy ziemi oraz obrzędów towarzyszących rolnictwu na Wyspach Trobrianda (przeł. A. Bydłoń, B. Leś). W: B. Malinowski. Dzieła. T. 4, 5. Warszawa: PWN.

Obrebski, J. (1976). The Changing Peasantry of Eastern Europe (red. B., J. Halpern). Cambridge, Mass: Schenkman Publishing Company.

Obrembski, J. (2001a). Folklorni i etnografski materijali od Poreče (red. T. Vražinovski). Vol 1. Skopje-Prilep: Institut za Staroslovenska Kultura, Matica Makedonska.

Obrembski, J. (2001b). Makedonski etnosocioloszki studii (red. T. Vražinovski). Vol 2. Skopje-Prilep: Institut za Staroslovenska Kultura, Matica Makedonska. Obrembski, J. (2002). Makedonski etnosocioloszki studii (red. T. Vražinovski). Vol 3. Skopje-Prilep: Institut za Staroslovenska Kultura, Matica Makedonska.

Obrębski, J. (1933). Family Organisation Among Slavs as Reflected in the Custom of Couvade. Typescript in archives of London School of Economics.

Obrębski, J. (1934). Czarna Magja w Macedonii. Kuryer Literacko-Naukowy. Dodatek do Ilustrowanego Kuryera Codziennego, 111, 6-8.

Obrębski, J. (1936). System religijny ludu macedońskiego. Kuryer Literacko-Naukowy. Dodatek do Ilustrowanego Kuryera Codziennego, 24, 13-14, 26, 11-12, 28, 11-13, 29, 11-12, 30, 13.

Obrębski, J. (1972). Obrzędowa i społeczna struktura wsi macedońskiej (przeł. W. Kowalski). Etnografia Polska, 16 (1), 201-213.

Obrębski, J. (2004). O metodzie funkcjonalnej Bronisława Malinowskiego, oprac. A. Engelking. Studia Socjologiczne, 173 (2), 35-63.

Obrębski, J. (2005a). Czarownictwo Porecza Macedońskiego. W: J. Obrębski. Dzisiejsi ludzie Polesia i inne eseje (red. A. Engelking), s. 25-52. Warszawa: IFiS PAN.

Obrębski, J. (2005b). Problem grup i zróżnicowań etnicznych w etnologii i jego socjologiczne ujęcie. W: J. Obrębski. Dzisiejsi ludzie Polesia i inne eseje (red. A. Engelking), s. 153-172. Warszawa: IFiS PAN.

Obrębski, J. (2005c). Skandal we wsi. W: J. Obrębski. Dzisiejsi ludzie Polesia i inne eseje (red. A. Engelking), s. 53-70. Warszawa: IFiS PAN.

Obrębski, J. (2005d). Struktura społeczna i rytuat we wsi macedońskiej (przeł. A. Engelking). W: J. Obrębski. Dzisiejsi ludzie Polesia $i$ inne eseje (red. A. Engelking), s. 71-88. Warszawa: IFiS PAN.

Obrębski, J. (2006). Social Structure and Ritual in a Macedonian Village. Sprawy Narodowościowe, 29, 286-295. 
Macedońskie Trobriandy. Józef Obrębski i pierwsze badania...

Obrębski, J. (2007). Polesie. Studia etnosocjologiczne (red. A. Engelking). T. 1. Warszawa: Oficyna Naukowa.

Rękas, J. (2018). Między stowami. Projektowanie folklorystyki konwersacyjnej na materiale celebracji Wodzic w Macedonii. Poznań: Wydawnictwo Naukowe UAM.

Rękas, J., Lučeska, E. (2015). Wodzicka narracja Józefa Obrębskiego i zarys projektu jej wspótczesnej aktualizacji. W: V. Petreska, J. Rękas (red.). Batkański folklor jako kod interkulturowy, s. 25-41. Skopje-Poznań: Instytut Folkloru im. Marka Cepenkova, Instytut Filologii Słowiańskiej UAM.

Risteski, L. S. (2011). Josef Obrebski's Anthropological Research on Macedonia. Etnoantropoloszki problemi, 6 (4), 837-858.

Spencer, J. (2008). Chtopi. W: A. Barnard, J. Spencer (red.). Encyklopedia antropologii społeczno-kulturowej, s. 155-157. Warszawa: Oficyna Wydawnicza Volumen.

Veselinovski, A. (2002). Moite seḱavanja na J. Obrembski i negovata sopruga Tamara. W: T. Vražinovski (red.) 70 godini od istražuvanjata na Jozef Obrembski vo Makedonija. Medžunaroden naučen sobir, Samokov, 14-16 septemvri 2001, s. 227-231. Prilep: Institut za Staroslovenska Kultura.

Vražinovski, T. (red.) (2002). 70 godini od istražuvanjata na Jozef Obrembski vo Makedonija. Medžunaroden naučen sobir, Samokov, 14-16 septemvri 2001. Prilep: Institut za Staroslovenska Kultura.

Vražinovski, T., Engelking, A., Halpern, J. M. (red.) (2003). Jozef Obrembski, Poreče 1932-1933. Jozef Obrebski, Macedonian Porech 1932-1933. Prilep-Skopje: Institut za Staroslovenska Kultura, Matica Makedonska.

Vražinovski, T., Karadžoski, V., Jovanovska-Rizoska, S. (red.) (2006). Jozef Obrembski - značaen istražuvač na narodnata kultura na Makedoncite. Skopje: Matica Makedonska.

Weintraub, W. (1994). O wspótczesnych i o sobie. Wspomnienia, sylwetki, szkice literackie (red. S. Barańczak). Kraków: Znak.

\section{ARCHIWALIA}

IEiAKUJ: Instytut Etnologii i Antropologii Kulturowej Uniwersytetu Jagiellońskiego w Krakowie, spuścizna Kazimierza Moszyńskiego.

LSE: London School of Economics and Political Science w Londynie, korespondencja Bronisława Malinowskiego. 
OC: „Obrebski Collection”, University of Massachussetts, Amherst, USA, spuścizna Józefa Obrębskiego, w tym niepublikowane prace i materiały: Czarna magia w Macedonii, Czarownictwo Porecza Macedońskiego, Giaurowie Macedonii. Opis magii i religii pasterzy z Porecza na tle zbiorowego zycia ich wsi, Skandal we wsi, Social Structure and Ritual in a Macedonian Village. 